\title{
MEMBINGKAI KEMBALI ILMU: KAJIAN KRITIS TENTANG DIKHOTOMI ILMU
}

\author{
Duski Samad \\ Guru Besar Ilmu Tasawuf Fakultas Tarbiyah IAIN Imam Bonjol Padang \\ e-mail: duski_samad@yahoo.com
}

\begin{abstract}
The existence of religious science and general science has been the long discourse that reduced the scientific world. The separation of these two sciences, often refers to as science dichotomy, has brought about serious implication not only to institutions and facilities, but also the main resources of these two branches. More serious implication of the separation of these two sciences has also created the gaps particularly on the superiority of the general science. This unhealthy and lack of objective view to religious science may not be taken for granted; comprehensive explanations of scientific resources, scientific method, and the historical existence of the two branches should be explored to reshape it in a strong unity and complementary.
\end{abstract}

\begin{abstract}
Abstrak: Diskursus tentang adanya ilmu agama dan ilmu umum sejak lama telah membuat dunia keilmuan menjadi kecil. Pemisahan ilmu agama dan ilmu umum yang sering juga disebut sebagai dikhotomi ilmu, juga berimbas jauh pada kelembagaan, sarana dan sumber daya dari kedua cabang keilmuan itu. Dampak lebih serius dari pemisahan kedua macam jenis ilmu tersebut telah membawa ketimpangan, khususnya pada pengarusutamaan ilmu umum dibanding ilmu agama. Pandangan kurang baik dan tidak obyektif terhadap ilmu-ilmu agama, tentu tidak harus dibiarkan begitu saja, penjelasan yang komprehensif tentang sumbersumber ilmu, metode ilmu, dan sejarah keberadaan kedua cabang ilmu itu harus diungkap guna untuk membingkainya kembali dalam satu kesatuan utuh dan saling melengkapi.
\end{abstract}

Kata Kunci: dikhotomi, ilmu-ilmu agama, ilmu-ilmu umum, integrasi.

\section{KEBERADAAN ILMU}

Sejarah tidak selalu linear, di satu masa sejarah pernah tidak lurus, berbelok atau dibelokkan, akibatnya orang di belakang hari menjadi ragu, bahkan ada yang kehilangan arah. Keadaan seperti itulah yang terjadi dalam sejarah ilmu pengetahuan. Keberadaan ilmu yang seharusnya obyektif dan tidak memihak, kini ilmu itu ikut menjadi alat propaganda dan kepentingan satu bangsa atau kelompok masyarakat tertentu. Dampak tak sengaja dari perjalanan yang salah itu menjadikan ilmu terkotak-kotak pada bidang yang sempit, ada yang menyebut ilmu umum, dan sekolahnya dinamakan sekolah umum, ilmu agama, sekolah tempatnya belajarnya pun dikatakan sebagai sekolah agama.

Realitas bahwa ada pemisahan (dikhotomi) ilmu itu telah membuat ilmu menjadi kerdil. Padahal Ilmu itu mestinya membuka pintu dunia lebih lebar lagi. Karena, Ilmu, adalah suatu alat potensial dalam hidup dan kehidupan manusia. Usaha dan pekerjaan apapun tanpa ilmu, besar kemungkinan akan sia-sia, kurang berhasil dan atau akan mengalami kegagalan. Ilmu merupakan suatu sifat yang mampu menyingkapkan segala sesuatu yang dituntut dan diinginkan. Ada ilmu yang bersifat sederhana; yaitu tidak memerlukan penilikan mendalam, dan ada pula ilmu yang bersifat rumit; yang memerlukan penilikan dan pengkajian lebih mendalam.

Ilmu adalah istilah yang biasa diartikan sebagai kesatuan pengetahuan terhadap beberapa aturan bidang kajian yang diteliti secara ilmiah, dan terhadap beberapa penerapan praktis dari fakta yang diperoleh melalui penelitian. Ilmu mempunyai dua unsur penting, pertama penelitian secara ilmiah, dan penerapan praktis dari fakta yang diperoleh melalui penelitian. Ada juga yang mendefinisikan ilmu dengan lebih sederhana, yaitu: suatu cabang kajian yang dipermasalahkan baik dengan suatu gabungan 
pembuktian maupun dengan pengamatan fakta secara sistematis guna menemukan keyakinan baru dalam bidang yang dikuasai. (Yuyun, 1994: $1-40)$.

Dalam al-Qur'an dikatakan bagaimana hebatnya kedudukan orang berilmu. ---Surat alMujadalah menciderai ayat 11 dikatakan, artinya: Hai orang-orang beriman apabila dikatakan kepadamu: "Berlapang-lapanglah dalam majlis", Maka lapangkanlah niscaya Allah akan memberi kelapangan untukmu. dan apabila dikatakan: "Berdirilah kamu", Maka berdirilah, niscaya Allah akan meninggikan orang-orang yang beriman di antaramu dan orang-orang yang diberi ilmu pengetahuan beberapa derajat. Allah Maha mengetahui apa yang kamu kerjakan.---. Tingginya derajat orang berilmu adalah disebabkan besarnya peran ilmu bagi kehidupan. Ilmu itu sangat luas dan meliputi berbagai aspek kehidupan. Luasnya cakupan ilmu, oleh sementara pakar hanya membagi ilmu dalam tiga kelompok; pertama, Ilmu Pengetahuan Alam (Natural Science); kedua, Social Science (Ilmu Pengetahuan Sosial); ketiga, Humaniora (pengetahuan kebudayaan). Lebih sederhana lagi, Yuyun S. Suriasumantri (1990: 93) membagi ilmu hanya dalam dua kelompok besar, Ilmu Pengetahuan Alam (Natural Science), dan Ilmu Sosial (Social Science), sedangkan "humaniora" (pengetahuan budaya) dimasukkan dalam "Ilmu Sosial".

Penyederhanaan klasifikasi ilmu sebagaimana di atas, sesungguhnya sudah ditemukan spiritnya al-Qur'an. Bila diteliti bahwa ayat pertama turun adalah (Iqra', artinya baca) QS. 96, Al 'Alaq 1-5. Membaca dan menulis, adalah "jendela ilmu pengetahuan". Dijelaskan, dengan membaca dan menulis akan mendapatkan ilmu pengetahuan yang sebelumnya tidak diketahui ('allamal-insana maa lam ya'lam). Wahyu Allah berfungsi sebagai sinyal dan dorongan kepada manusia untuk mendalami pemahaman sehingga mampu membaca setiap perubahan zaman dan pergantian masa.

Keistimewaan ilmu lainnya, menurut wahyu Allah; Yang mengetahui pengertian ayat-ayat mutasyabihat hanyalah Allah dan orang-orang yang dalam ilmunya (QS.2:7). Orang berilmu mengakui bahwa tidak ada Tuhan selain Allah (QS.3:18). Di atas orang berilmu, masih ada lagi yang Maha Tahu, (QS.12:76). Bertanyalah kepada ahli ilmu kalau kamu tidak tahu, (QS.16:43, dan 21:7). Jangan engkau turut apa-apa yang engkau tidak mempunyai ilmu tentang itu (QS.17:36). Kamu hanya mempunyai ilmu tentang ruh sedikit sekali (QS.17:85). Memohonlah kepada Allah supaya ilmu bertambah (QS.20:114). Ilmu mereka (orang yang menolak ajaran agama) tidak sampai tentang akhirat (QS.27:66). Hanyalah orang-orang berilmu yang bisa mengerti (QS.29:43). Yang takut kepada Tuhan hanyalah orang-orang berilmu (QS.35:28). Tuhan meninggikan orang-orang beriman dan orang-orang berilmu beberapa tingkatan (QS.58:11). Tuhan mengajarkan dengan pena (tulis baca) dan mengajarkan kepada manusia ilmu yang belum diketahuinya (QS.96:4-5).

\section{SUMBER ILMU}

Mengenai sumber ilmu pengetahuan ada beberapa pandangan yang mengemuka. Perbedaan pendapat tentang sumber ilmu pengetahuan itu di dasarkan pada realitas pengetahuan yang diperoleh manusia. Setidaknya setiap saat orang memperoleh 4 (empat) macam pengetahuan yang saling bersambung. Pertama, pengetahuan yang bersumber dari hal yang bersifat empiris. Pengetahuan jenis empiric ini diperoleh melalui jalur observasi atau pengamatan (observerable) dan pengukuran tertentu (measureable) dengan menggunakan instrumen indrawi, ilmu jenis ini lazim disebut sebagai ilmu-ilmu alam (natural science). Kedua, manusia juga bisa mendapatkan pengetahuan melalui instrumen emosi (sense), pengetahuan jenis ini akan muncul dalam bentuk pengetahuan seni dan budaya (ilmu humaniora). Ketiga, ilmu juga didapatkan melalui penggunaan rasio atau akal cerdasnya dengan memahami fonemena yang ada, itulah kemudian menjadi ilmu sosial (social sience). Keempat, diyakini oleh berbagai komunitas manusia bahwa ada pula ilmu yang diperoleh berdasarkan pengalaman keruhanian orang yang suci (Nabi dan Rasul), yang terakhir ini disebut sebagai ilmu agama yang lazimnya bersifat normatif, dogmatis dan transenden.

Perdebatan tentang sumber ilmu pengetahuan ini terjadi karena ada perbedaan mendasar tentang alat (instrument) mana yang 
dapat membuat manusia mengetahui. Ilmuwan Muslim membagi sumber ilmu pengetahun itu ke dalam tiga bagian saja. Sumber adalah benda-benda atau entitas-entitas yang potensial untuk dijadikan bahan pengetahuan manusia. Ketiga macam sumber ilmu tersebut adalah: pertama, benda-benda yang bisa diinderai (mahsusat/sensible), kedua, entitas-entitas yang hanya bisa dipahami oleh akal (ma'qulat) intelligibles), ketiga, terakhir wahyu (Mulyadhi Kartanegara, 2000: 121). Ilmuwan Muslim dalam menetapkan prioritas ilmu pengetahuan yang hendaknya dikuasai ternyata juga berbeda, akan tetapi berkenaan dengan sumber ilmu pengetahuan yang paling tinggi dan otoritatif mereka sepakat adalah wahyu. Otoritas wahyu itu terletak pada sumber wahyu itu sendiri, yaitu Allah SWT. yang sering disebut kebenaran (the truth/al-haqq). Ia menyampaikan wahyu secara langsung atau melalui malaikat yang terpercaya (al-ruh al-amin), sehingga tidak ada keraguan di dalamnya (la rayba fihi). Kebenarannya adalah mutlak, dan karena itu wahyu dalam hal ini alQur'an selalu dijadikan parameter, dengan mana semua informasi dari sumber yang lain (mahsusat dan ma'qulat) dicek dan dicocokkan. (Mulyadhi Kartanegara, 2000: 121).

Pada masa berikutnya setelah wahyu, maka ilmuwan Muslim berbeda dalam menempatkan sumber ilmu pengetahuan, begitu juga halnya dalam mengurut prioritas ilmu. Perselisihan tentang prioritas ilmu, antara ilmu utama dengan ilmu pilihan, antara ilmu primer dengan ilmu sekunder pada akhirnya bermuara pada penempatan posisi akal (reason) dan persepsi indrawi (sense-perception). Ujung dari perbedaan ini, akhirnya memicu lahirnya perbincangan tentang adanya ilmu agama dan ilmu umum, jika dilihat kepada akar sejarah umat Islam, ini sesungguhnya berasal dari pengaruh dominasi antara ahli fiqh dengan ilmuwan muslim. Sepanjang sejarah kelembagaan pendidikan Islam, baik madrasah maupun al jami'ah diabdikan terutama kepada al-'ulum al-Islamiyah atau tepatnya al- 'ulum al-diniyahilmu agama dengan penekanan khusus pada bidang fiqh, tafsir dan hadis. Dengan demikian ilmu-ilmu "non-agama" atau "keduniaan" (profan) khususnya ilmu alam dan eksakta ---yang merupakan akar-akar dari pengembangan sains dan teknologi--- sejak awal perkembangan madrasah dan al-jami'ah sudah berada pada posisi yang marjinal. Meskipun Islam pada dasarnya tidak membedakan nilai ilmu-ilmu agama dengan ilmu-ilmu non agama (ilmu umum), akan tetapi dalam praktiknya, supremasi lebih diberikan kepada ilmu-ilmu agama. Hal ini disebabkan sikap keagamaan dan kesalehan yang memandang bahwa ilmu-ilmu agama sebagai "jalan tol" menuju Tuhan. (Azyumardi Azra, 1994: vii).

Runtuhnya reputasi ilmu-ilmu umum di lingkungan umat Islam, tidak saja karena perlakuan yan tidak adil oleh penguasa dan dominasi kaum fuqaha, akan tetapi ia juga punya kaitan erat dengan kekalahan aliran Mu'tazilah dalam percaturan pemikiran Islam. Sebelum Mu'tazilah hancur sebagai aliran teologi rasional, ketika khalifah al Ma'mun pada dinasti Abbasiyah (198-218H/813-833M), ilmuilmu umum mendapat tempat tersendiri dalam wacana keilmuan di masyarakat dan lembaga pendidikan madrasah. Mempelajari ilmu-ilmu umum yang bertitik tolak dari nalar dan kajiankajian empiris oleh kaum fuqaha dikatakan sebagai ilmu yang tidak Islami, bahkan ada yang menyebutkan makruh dan yang lebih ekstrem mengatakannya sebagai haram, ini kemudian menjadikan ilmu umum semakin tidak populer dan tidak menjadi penting dalam kehidupan sosial masyarakat umat Islam. Dampak lebih jauh dari pemarjinalan ilmu-ilmu umum menjadikan ia dicurigai dan dalam pelaksanaannya dihapuskan dari kurikulum madrasah dan al-jami'ah. Kaum intelektual yang masih berminat kepada ilmu-ilmu umum itu, terpaksa mempelajarinya secara sendirisendiri, dan atau bahkan "di bawah tanah", karena dipandang sebagai ilmu-ilmu "subvertsive" yang dapat menggugat kemapanan doktrin mapan Sunni, terutama dalam bidang kalam (teologi) dan fiqh. (Azyumardi Azra, 1994: vii).

Pertanyaan yang sering mengemuka disaat mengkritisi sejarah pendidikan dan intelektual Islam adalah mengapa kaum fuqaha sebagai intelektual Islam yang cukup kuat mempercayai penggunaan akal, dengan konsep ijtihadnya, terlalu mudah mengeliminir penggunaan akal pada hal-hal yang bersifat obyektif dan empiris, sebagaimana dipakai 
dalam ilmu-ilmu umum? Pertanyaan yang lebih tegas lagi mengapa legalisme fiqih dan syari'ah bisa begitu dominan terhadap lembaga pendidikan dan gerakan intelektual Islam? Di antara jawaban analisis yang patut dikemukan adalah bahwa ada tiga alasan, pertama, ini terjadi berkaitan dengan pandangan tentang ketinggian syari'ah Islam dan ilmu keagamaan lainnya. Kedua, secara institusional lembagalembaga pendidikan Islam klasik sejak awal berdirinya Madrasah Nizhamiyah yang didirikan oleh Wazir Nizhamiyah pada 1064 M, memang dikuasai oleh ahli-ahli ilmu agama semata. Ketiga, berkaitan dengan pendirian Madrasah dan lembaga pendidikan Islam, hampir semuanya didanai oleh wakaf, infaq dan sadaqah dermawan muslim, yang secara teologis lebih merasa tinggi pahalanya jika wakaf, infaq dan sadaqah itu diberikan kepada sekolah agama.

\section{INTEGRASI ILMU}

Jika dibuka kembali lembaran sejarah peradaban Islam, akan didapati cuplikancuplikan sejarah kegemilangan dan kejayaan Islam yang sungguh luar biasa. Kedigdayaan Islam mampu menguasai seluruh sistem dan konsep peradaban dunia. Tidak hanya ranah ekonomi, politik, budaya saja yang dikuasai, bahkan ilmu pengetahuan dan teknologi menjadi sangat dominan dan mampu menjadi kiblat ilmu pengetahuan bagi dunia waktu itu.

Tradisi pengkajian ilmu di kalangan umat Islam dengan semangat, kecintaan dan kesungguhan dalam belajar, menghafal, diskusi, menulis dan mencari ilmu hingga ke lintas negara menjadi bagian yang tidak terpisahkan dari kehidupan umat Islam waktu itu. Maka wajar saja, buah dari peradaban ilmu tersebut, bermunculan tokoh-tokoh besar ilmuan dan ulama, seperti, Imam Al-Ghazali, Al-Farabi, Ibnu Sina, Al-Kindi, As-Suyuthi, Ibnu Rusyd, Ibnu Nafis, Ibn Khaldun, dan lain sebagainya. Mereka menjadi referensi umat dalam berbagai persoalan kehidupan. Mereka memahami dan menguasai berbagai disiplin ilmu. Selain ilmu agama, seperti ilmu Tafsir, Hadis, Aqidah, Fiqh dan Tasawuf, mereka juga menguasai dan pakar dalam ilmu Fisika, Sastra, Kedokteran, Kimia, Sejarah, Teknologi dan ilmu-ilmu umum lain- nya. Mereka tidak memisahkan antara ilmu agama dan ilmu umum, meskipun ada perbedaan ruang kajian kedua ilmu tersebut. Menariknya, pengkajian ilmu pengetahuan dalam tradisi Islam selalu totalitas dan selalu berpegang pada aspek ilahiyyah dan juga adab. Sehingga, semakin luas ilmu yang diperoleh maka semakin tinggi pula amal yang dihasilkan.

Namun persoalan kemudian ketika umat Islam mengalami kemunduran dan hampir seluruh ranah dikuasai oleh peradaban Barat, identitas keilmuan Islam tersebut mulai pudar. Seluruh konsep ilmu pengetahuan diubah dan disesuaikan dengan nilai-nilai dan tradisi keilmuan Barat. Sebagaimana diketahui, bahwa identitas peradaban Barat tak lepas dari paham sekuler, yaitu pemisahan antara agama dan seluruh persoalan publik, baik ilmu pengetahuan, politik maupun ranah lainnya. Ini memang ciri khas peradaban Barat. Pemisahan (dikhotomi) terhadap ilmu pengetahuan adalah bagian dari paham tersebut dan dampaknya merambah dalam kultur keilmuan saat ini. Hal ini adalah problem yang serius yang dihadapi umat Islam.

Persoalan dikhotomi ilmu tersebut memang tak lepas dari kungkungan metodologi dan epistimologi keilmuan barat. Mengangungkan ilmu pengetahuan (akal) dan menyingkirkan peran agama di dalamnya, memang bagian yang tak bisa terpisahkan dari metodologi mereka. Sejak periode modern, post-modern hingga saat ini identitas tersebut masih sangat melekat pada tradisi mereka. Dampak dari dikhotomi ilmu sebenarnya sangatlah besar, dan persoalan ini yang menjadi salah satu yang faktor kemunduran pada umat Islam. Realitas tersebut sederhana dapat dilihat, misalnya dalam dunia pendidikan, banyak sarjana agama yang mengabaikan dan tidak paham ilmu umum sehingga tidak mampu menjawab problematika keilmuan dan tekhnologi modern, sehingga menghambat penyebaran nilai-nilai Islam dalam ranah yang lebih luas. Sebaliknya banyak sarjana umum yang tidak paham agama, sehingga berefek pada dekadensi moral, dan tentu ini merusak nilai kemurnian ilmu itu sendiri. di sinilah terlihat ketidakseimbangan, ketika sarjana agama hanya mampu menguasai ranah Syariat dan sarjana umum yang hanya ahli di bidang umum. 
Selain itu, realitas dikotomi ilmu tersebut juga terjadi pada instansi sekolah yaitu terjadinya pemisahan sekolah umum dan agama. Dalam muatan kurikulum misalkan, sekolah umum dominan ilmu yang diajarkan hanya ilmu umum (science) dan tidak digabungkan dan diarahkan pada nilai-nilai agama. Sehingga metode tersebut akan tergiring pada pola pikir yang sekuler dan berdampak pada degradasi moral, akhirnya memicu pada rusaknya generasi Islam, disebabkan pondasi ilmu agama yang lemah. Pada akhirnya, agama dianggap tidak penting dalam persoalan ilmu dan dunia. Dari sinilah yang kemudian banyak umat Islam tergiring pada pemahaman sekuler. Pada sekolah sampai perguruan tinggi, konsep ini terus dipraktikkan secara sadar atau tidak dapat mempengaruhi gaya hidup dan pola pikir ummat. Hal ini adalah satu di antara contohcontoh besar lainnya atas dampak dari dikhotomi ilmu.

Melihat dampak yang ditimbulkan dari pengaruh dikotomi ilmu tersebut, perlu sebuah upaya yang serius dengan membersihkan dan menyingkirkan konsep sekuler tersebut dari ranah ilmu pengetahuan. Kemudian memperbaharuinya dengan konsep keilmuan Islam yang pernah berjalan pada masa kegemilangan peradaban Islam abad pertengahan dulu. Mungkin kendalanya adalah terletak pada bagaimana cara untuk merubah konsep tersebut hingga sistem keilmuan benar-benar bisa berjalan secara bersamaan dan saling terkait tanpa terjadi dikhotomis atau parsial.

Syekh Naquib Al-Attas menawarkan gagasan konsep yang perlu dilakukan untuk menyelesaikan problem tersebut yaitu dengan cara islamisasi ilmu, terutama ilmu pengetahuan kontemporer dan modern karena ilmu-ilmu kontemporer dan modern telah mengalami sekularisasi dengan worldview peradaban barat. Metode pengkajian ilmu dibarat bergantung sepenuhnya kepada kaidah empiris, rasional dan materialistik. Perolehan ilmu melalui wahyu dan kitab suci diabaikan dan dipandang rendah. Ilmu-ilmu dibarat tidak berlandaskan nilai-nilai transenden dan juga tidak berkaitan dengan kepercayaan agama. Hal ini sangat berlawanan dari worldview Islam.
Syekh Naquib Al-Attas menegaskan bahwa, upaya islamisasi ilmu tersebut sangat penting dilakukan. Sebagai cara untuk membersihkan pengaruh-pengaruh negatif dalam ilmu pengetahuan dan kemudian memasukkan konsep-konsep keilmuan berdasarkan Worldview Islam. Sehingga antara ilmu umum dan agama tidak terpisahkan dan saling integral. Membiarkan ilmu dalam kondisi terpisah dari agama, akan melahirkan manusia yang memiliki paradigma sekuler, dan akhirnya melahirkan sikap yang cenderung mencampakkan Tuhan dan agama dari kehidupan dunia, tentu tidak sama halnya dengan kaum atheis yang menafikan Tuhan. http://rezaaceh.wordpress. com

Pandangan lain yang juga patut dipertimbangkan adalah menengok perjalanan sejarah dikhotomi antara ilmu agama dan ilmu umum yang sudah melembaga dan menstruktur dalam masyarakat, maka kiranya patut diupayakan langkah-langkah strategis untuk merukunnya dalam satu bingkai yang saling melengkapi. Struktur keilmuan yang bersumber dari alQur'an dan Hadis yang dikembangkan di Perguruan Islam sejak awal berdirinya sampai saat terakhir masih berkutat pada konseptual hegemoni ilmu agama sebagai ilmu tertinggi dan kurang memberikan perhatian pada ilmuilmu umum. Pola pikiran konseptual yang abstrak dan cenderung dalam bentuk doktrin ini tentu harus dapat dijabarkan sedemikian rupa, dengan memberikan kesempatan kepada semua pihak yang terlibat untuk mengembangkan keilmuan yang berbasis pada eksperimen, observasi dan pendekatan ilmiah lainnya. Ilmu pengetahuan yang berbasis pada al-Qur'an dan sunnah dapat direkatkan untuk digabungkan sedemikian rupa antara ilmu agama dan ilmu umum dalam satu kesatuan. Ilmuwan dituntut untuk menolak dikhotomi atau pemberian kategorisasi pada ilmu, sebagai ilmu umum dan ilmu agama. Sebab kategorisasi semacam itu adalah janggal dan rancu. Oleh karena, Islam pada dasarnya tidak dapat dikatakan sebagai ajaran yang bersifat khusus, sebab lingkup ajaran Islam luas, universal dan menyangkut berbagai aspek kehidupan. Masalah yang perlu ditegaskan adalah jika ilmu agama dan ilmu umum dikatakan sebagai ilmu, maka ilmu agama bersumber dari wahyu ilahi dan ilmu 
umum berasal dari observasi, eksperimen dan penalaran ilmiah manusia.

Kewajiban untuk mengintegrasi (memadukan) ilmu agama dan ilmu umum dapat dimulai dari kerja akademis yang pada akhirnya akan berujung pada misi teologis. Kedua bidang ilmu yang berasal dari sumber yang berbeda (Allah dan Manusia) tentu harus dikaji secara bersama-sama dan simultan, mungkin yang harus ditegaskan adalah bahwa bidang ilmu agama itu bersifat fardu ain sedangkan pengetahuan umum itu fardhu kifayah. Logika ilmiah yang hendaknya terbangun kokoh dari integrasi ilmu itu adalah adanya kesatupaduan antara ayat-ayat ilahiyah dengan ayat-ayat kauniyah. Maka dengan demikian, struktur keilmuan yang diupayakan dalam pengintegrasian ilmu-ilmu umum dan ilmu agama tentu tidak dapat dibiarkan berjalan tanpa paradigma dan epistemologi yang jelas dan terukur. Pengkajian dan diskusi yang mendalam dan intensif tentang bangunan struktur keilmuan yang akan dijadikan acuan harus dapat ditunjukkan melalui metafora tertentu.

Untuk mengetahui bagaimana ilmuwan muslim mengintegrasikan ilmu umum dengan ilmu agama dapat dilihat dalam pola penafsiran mereka, misalnya dalam memahami pengertian bahwa kejadian langit dan bumi merupakan tanda kekuasaan, ke Maha Esaan Allah bagi orang-orang yang mempunyai akal pikiran. Dalam penafsiran ayat: Inna fi khalaqi alsamawatiwa al-Ardh, Syekh Mahmud al-Alusiy menjelaskan bahwa penciptaan dan pewujudan langit dan bumi adalah termasuk keajaiban dan keindahan, sedangkan dalam penafsiran ayat: Wa ikhtilaf al lail wa al-Nahar ia menjelaskan dengan saling berkejarannya siang dan malam adalah dikaitkan dengan perputaran bumi dengan putaran rotasi, yaitu berputarnya bumi mengelilingi matahari melalui jalannya yang berbentuk elip, sekali dalam satu tahun (Syamsiyah). Dengan demikian, terjadilah siang dan malam, yang tepat dengan kutub, baik kutub selatan maupun kutub utara siangnya lebih panjang dari pada malamnya atau sebaliknya pada musim-musim tertentu, dan untuk tempattempat tertentu pula terjadi empat musim yaitu musim gugur, dingin, semi dan musim panas. (Syakh al-Mahmud al-Alusy, t.t: 155-156).

Alusiy berpendapat bahwa dalam tata surya ini matahari tetap di tempatnya, sedangkan semua planet-planet beredar mengelilinginya. Sebagai satelit bumi, bulan mengelilingi bumi sekali dalam sebulan (Qamariyah), karena bumi mengalami perputaran revolusi, maka sekali-kali timbul gerhana matahari atau gerhana bulan, akhirnya al-Alusy menyebutkan bahwa memang tidak terdapat satu hadis pun mengenai bumi dan langit ini karena masalah ini ada di luar kepentingan syara'. Sayyid al-Mahmud Alusy, t.t:156)

Sayyid Qutub berbeda dalam menafsirkan ayat ini, ia menjelaskan bahwa disini ada hakekat yang dalam, jelasnya bahwa keadaan alam ini merupakan kitab yang terbuka, yang mengandung dalil-dalil dan tanda-tanda iman yang mempunyai latar belakang hikmah, diwahyukan Tuhan bahwa di balik kehidupan dunia ini ada akhirat, ada perhitungan ada balasan, hanya orang yang mempunyai akal pikiran yang tahu dalil-dalil ini, hanya bisa melihat hikmah ini, hakikat alam inilah merupakan hubungan kuat antara fitrah alam dan fitrah manusia, satu segi merupakan dilalah kejadian alam untuk menuju Sang Kaliq, segi lain menuju kepada hikmah dan tujuan wahyu itu sendiri. (Sayyid Qutub, 1967: 94).

Selanjutnya Sayyid Qutub menjelaskan bahwa ada dua hakekat penting pengenai Tafakkaru fi khalqillah yaitu, (1) Tafakkur fi khalqillah, tadabbur fi kitab al-kaum al-maftuh, dan mengikuti kuasa Allah yang berbuat, kuasa Allah, yang mengerahkan alam dan membuka halaman-halaman, kitab al-kaum ini, merupakan ibadah kepada Allah dan zikrullah secara tulus. Kalau ilmu-ilmu kauniyah membahas persoalan kealaman secara murni, dalam keadaanya, aturannya, rahasianya, berhubungan dengan zikir terhadap khaliq, baik keagungan atau keutamaannya, maka itu mengarah kepada ibadah kepada khaliq dan pasti kehidupan dengan ilmu-ilmu itu bersifat materialis maka akan memutuskan hubungan ilmu-ilmu itu bersifat materialis maka akan memutuskan hubungan antara kauniyah dengan khaliknya, justru itu ilmu yang merupakan anugerah Allah yang paling baik terhadap manusia, akan 
berubah menjadi kutukan yang akan menempatkan manusia ke dalam neraka. (2) Ayat-ayat Allah tentang kauniyah pada hakekatnya tidak jelas kecuali bagi hati nurani yang selalu ingat dan selalu beribadah kepada Allah, sedangkan orang-orang yang berzikir kepada Allah, dengan berdiri, duduk, berbaring yang mereka itu bertafakur tentang kejadian kaum ini mereka itulah yang terbuka penglihatan mereka tentang hakekat besar yang tercakup pada kejadian langit, bumi, siang dan malam, mereka itulah yang dapat menempatkan latar belakang kaum ini kepada program Allah yang menuju keselamatan, kebaikan, tetapi apabila mereka membatasi kehidupan dunia yang lahir saja dan menghubungkannya pada rahasia sebagian kekuatan kauniyah, tidak seperti hubungannya dengan program Allah, maka mereka itu merusak dirinya dalam rahasia kauniyah dan menempatkan dirinya ke dalam neraka. (Sayyid Qutub, 1967: 190).

Muhammad Qutub dalam mengulas Ulu al-Albab al-Izina yatafakkarun menjelaskan mereka itu adalah orang-orang yang mencurahkan kekuatan pikirannyaa untuk memikirkan ayat-ayat Allah tentang alam ini, tetapi mereka bukan hanya sekedar berpikir secara polos, serta lupa fakta yang nyata, dan bukan pula memikirmikir terjauh dari Allah, hal ini dapat menyesatkan dirinya melainkan mereka dengan Allah, mereka tidak memikirkan ayat-ayat Allah tanpa tujuan melainkan segara menghubungkan kepada sasaran mereka dengan berdo'a Rabbana ma khalaqta haza bathila. (Sayyid Qutub, 1967: 94).

Pembahasan keilmuan yang memadukan antara pemahaman ilmiah obyektif dengan teologis sebagaimana ditunjukkan di atas adalah satu model integrasi ilmu yang dapat dijadikan contoh di masa datang.

\section{SIMPULAN}

Pemisahan ilmu-ilmu agama dengan ilmu-ilmu umum yang masih saja berlangsung sampai saat terakhir adalah bentuk dari perjalanan sejarah gelap yang harus diluruskan. Ilmu pada dasarnya adalah netral dan merupakan hak Allah yang dianugerahinya kepada siapa saja yang belajar dan bekerja sungguh-sungguh untuk mendapatnya. Wahyu adalah sumber paling otoritatif untuk segenap macam cabang ilmu pengetahuan. Ilmu yang dikembangkan melalui observasi, logika dan eksperimen adalah jenis ilmu yang terus harus dikembangkan guna menciptakan teknologi bagi kemudahan hidup manusia. Ilmu-ilmu yang berkembang karena adanya pencarian rasio, rasa dan logika juga dituntut untuk dikembangkan guna menciptakan peradaban yang lebih baik dan maju. Sedangkan ilmu yang bersifat normatif, doktrin yang bersumber dari wahyu Allah SWT adalah merupakan pedoman abadi yang absolut adanya. Dapat juga dikatakan bahwa agama dan sains itu sejalan. Agama mencoba memahami tujuan dan arti dari alam ini, ilmu pengetahuan mencoba memahami fungsi dan strukturnya. Jika ada pengertian, struktur pasti banyak kaitannya dengan arti, dalam jangka panjang keduanya pasti akan sejalan. Sangat tidak mungkin jika dikatakan bahwa hukum fisika yang mengatur kehidupan di dunia ini hanya kebetulan. Sains dan agama semestinya menemukan dasar yang sama. Perbedaannya sebenarnya kabur atau superfisial bahkan jika dilihat sifat realnya sama. Temuantemuan di bidang astronomi telah membuka mata manusia kepada agama. Fakta bahwa alam ini ada awalnya merupakan hal yang menakjubkan, mana mungkin kejadian itu ada tanpa Tuhan? Islam tidak memisahkan agama dengan sains. Tuhan adalah Maha penguasa dan sumber kebenaran.

\section{DAFTAR RUJUKAN}

Azyumardi Azra. 1994. Pengantar dalam Buku Pendidikan Tinggi dalam Islam. Charles Michael Stanton, Jakarta: PT. Logos.

http://rezaaceh.wordpress.com/2010/10/28/prob lem-dikotomi-ilmu. Diakses pada tanggal 8 Maret 2012.

Mulyadhi Kartanegara. 2000. Mozaik Khazanah Islam, Jakarta: Paramadina.

Nurcholid Madjid. 1994. Khazanah Intelektual Islam. Jakarta: Bulan Bintang.

Sayyid Qutub. 1967. Munhaj al-Tarbiyah alIslamiah, t.t: t.p. 
Al-Sayyid al-Mahmud al-Alusy. t.t. Ruh alMa'aniy. Juz IV. Beirut: Ihya' al-Turas alArabiy.

Yuyun S. Suriasumantri. 1994. Ilmu dalam Perspektif, Jakarta: Gramedia. 